\title{
CORAK PEMIKIRAN DAN METODE IJTIHAD IBN TAYMIYYAH
}

\author{
Zainal Abidin \\ STAIN Datokrama Palu \\ Email: zainalabidin@yahoo.com
}

\section{Abstract}

This article discusses the thought color and methods of ijtihad of Ibn Taymiyyah, one of the most influential figures in the movement of of Islamic thought renewal. He raised a number of criticisms of the logician. The arguments he used indicated that he is a thinker of empiricism. This empiricism complexion coloring intellectual works in various fields. In the field of fiqh, in the beginning he was a follower of the school of Hanbaliyah, however, in further development he performed ijtihad independently without being tied down by other schools. That is why Ibn Taymiyya was known as a mujtahid mutlaq. Although in performing ijtihad he remains grounded in the Qur'an and Sunnah as well as admits the ijmâ' and qiyâs as a source of Islamic law, his thoughts are often different from other scholars of his time, both on the aspect of methodology and the results of his ijtihad.

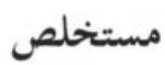

هذه المقالة باحثة عن نوع الفكرة و طريقة إجتهاد ابن تيمية، هو احد الرجال الذين يؤثرون بتديد

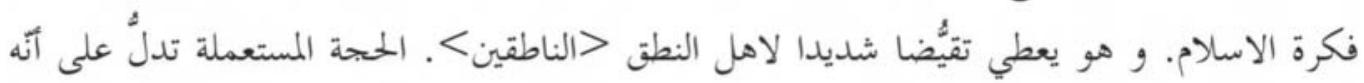

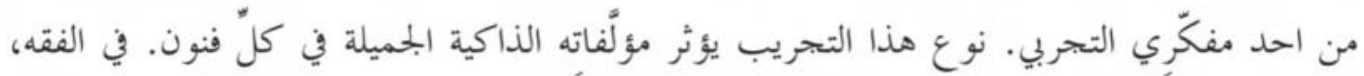
هو يفتقد مذْهب الحنبلة اولاً، ولكنّه يجتهد بنفسه في ايام الأتية دون اتصال الآخر. لهذا ابن تيمية

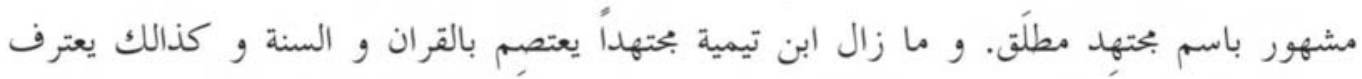

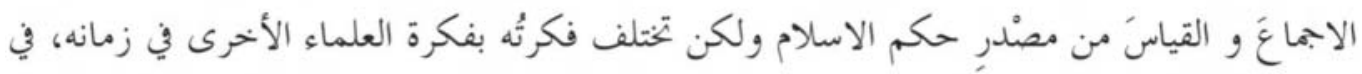
وجه الطريقة و نتاج إجتهاده.

Keywords: empirisme, logika, ijtihad, mujtahid mutlak, metodologi hukum 


\section{A. Pendahuluan}

Kebudayaan Islam pernah memberikan andil dalam perjalanan sejarah dunia (dari abad ke-7 sampai ke-14), dan kemudian tenggelam dalam masa enam abad terakhir. Di sini keinginan untuk mengembalikan peran dunia Islam dalam peradaban dunia menjadi penting untuk dicermati. Respons terhadap itu setidaknya adalah dengan melakukan tajdîd al-fahm (pembaharuan pemahaman).

Bagi pendukung tajdîd, ada sesuatu yang salah dalam pemahaman kaum muslim terhadap ajaran-ajaran dasar Islam. Umat Islam terdahulu, khususnya generasi enam abad terakhir, terlalu terpaku pada aturan-aturan fikih yang rigid, dan terpola oleh pemikiran kalam yang bersifat klasik skolastik ${ }^{1}$. Padahal semua model pemikiran Islam klasik itu juga dibentuk oleh persoalan-persoalan khusus yang dihadapi oleh generasi tertentu.

Paling tidak, ada dua faktor yang membuat isu pembaruan Islam menjadi aktual sekaligus kontroversial sepanjang pemikiran Islam. Pertama, watak keuniversalan Islam, yang meniscayakan pemahaman yang selalu baru untuk menyikapi perkembangan kehidupan manusia yang senantiasa berubah. Kedua, watak kemutlakan Islam, yang berimplikasi pada pandangan bahwa Islam adalah sistem nilai yang melebihi sistem nilai lain dan bahkan satu-satunya yang absah.

Dari sini, ada asumsi bahwa ijtihad menjadi tugas yang ekslusif dan menuntut persyaratan yang ketat, serta hanya bisa dilakukan oleh orang-orang berkualifikasi saja. Penggambaran ijtihad seperti ini telah melahirkan persepsi salah, yaitu pentabuan ijtihad. Dalam perkembangannya, pentabuan ini dapat pula dilihat sebagai kelanjutan masa kegelapan dalam pemikiran Islam.

Pada dasarnya, seperti pernyataan Iqbal, "ijtihad merupakan prinsip gerak dalam Islam."” Dengan kalimat ini, Iqbal tampaknya hendak mengingatkan bahwa tanpa ijtihad yang kreatif dan terus-menerus, kaum Muslimin akan dilanda kebekuan berfikir, taklid, dan penolakan terhadap segala sesuatu yang baru. Dalam konteks inilah, sosok Ibn Taymiyyah, salah seorang tokoh penggagas tajdîd, penting untuk dicermati. Tulisan ini ingin melihat corak pemikiran dan metodologi ijtihad yang diterapkannya.

1 M. Arkoun, al-Islâm: al-Akhlâq wa al-Siyâsah, Terj. Hashim Saleh, (Beirut: Markaz alInmâ’ al-Qawmî, 1990), hal. 172.

2 Dikutip dalam "Polemik Sosiologi Pembaruan Pemikiran Islam Nurcholish Madjid", dalam Jurnal Ulumul Qur'an, Vol. 4, No. 1 (1993), hal. 46. 


\section{B. Riwayat Hidup Ibn Taymiyyah}

Nama lengkap Ibn Taymiyyah adalah Taqiyuddin Abu Abbas Ahmad Ibn Abd. Halim Ibn Abd. Salam Ibn Muhammad Ibn Taymiyyah. Dia lahir di Harran dekat Damaskus, Suria, pada tahun 611 H/1263 M, lima tahun setelah jatuhnya Baqdad ketangan bangsa Tartar yang berarti berakhirnya dinasti $\mathrm{Abbasiah}^{3}$ atau beliau lahir lebih setengah abad sesudah wafatnya Ibn Rusyd. Beliau lahir ketika dunia Islam mengalami stagnasi dan disintegrasi dalam berbagai bidang karena perpecahan internal antara dinasti Islam serta permusuhannya dengan Barat-Kristen. Dia wafat di Damaskus pada malam Senin 20 Zulqaidah 728 H./26 September 1328 M. $^{4}$

Pendidikannya dimulai dengan belajar Alqur'an dan al-hadits pada ayahnya sendiri, kemudian ia masuk sekolah di Damaskus, mempelajari berbagai ilmu keislaman. Usia 10 tahun ia telah mempelajari kitab-kitab hadits utama (Musnad Ahmad, al-Kutub al-Sittah), hafal Alqur'an, dan mendalami bahasa arab dari Ibn Abd. Al-Qawi. Selanjutnya ia tertarik mendalami ilmu kalam dan filsafat dan menjadi ahli kedua bidang itu. Beliau berhasil menyelesaikan seluruh pendidikannya di usia 20 tahun dan diangkat menjadi guru besar mazhab Hambali menggantikan ayahnya. Ia dikenal dengan gelar Syaikh al-Islam. Ia orang yang sangat gigih menentang segala pendapat yang tidak sejalan dengan pikirannya. Hampir seluruh karya-karyanya ditulis dalam rangka polimeknya dengan ulama-ulama yang ditentangnya, baik sezaman maupun sebelumnya. Di antara karya-karyanya yang terkenal adalah; al-Radd 'alâ alMantiqîn, Bayân Muwafaqât Sharîh al-Ma'qûl li Shahîh al-Manqûl, Itsbât al-Ma'âd, Tsubût al-Nubuwah al-Radd 'alû al-Hulûliyyah Wa al Ittihâdiyah, Minhaj al-Sunnah al-Nabawi Ishlâh al-Râ’i wa al-Ra'iyyah dan lain-lain. Menurut al-Zahabi, tulisantulisan Ibn Taymiyyah yang berhasil ditemukan hingga sekarang ini tidak kurang dari 500 jilid. Ibn Taymiyyah wafat pada tahun $1328 \mathrm{M} / 728 \mathrm{H}^{5}$

Sejarah mencatat kondisi ketika Ibn Taymiyyah hidup, ada beberapa kondisi yang mengkhawatirkan:

1. Semakin banyaknya bid'ah dan syirik, lebih-lebih kesyirikan yang terdapat di sekitar masyahid dan kuburan yang diagungkan. Juga i’tiqod (keyakinan) yang

3 Munawir Sjadzali, Islam dan Tata Negara, Ajaran, Sejarah dan Pemikiran, (Cet. II; Jakarta: Universitas Indonesia, 1990), hal. 79

4 Muhammad b Ismâ'îl b Kathîr, al-Bidâyah wa al-Nihâyah, Jilid 9, (Beirut: Dâr al-Fikr, t.th.), hal. 135 hal. 79

Hamka Haq, Dialog Pemikiran Islam, (Cet. I;Ujung pandang: Yayasan al- Ahkam, 1995), 
batil terhadap orang yang hidup dan yang mati. Mereka diyakini dapat memberi manfaat dan dapat memberi kesusahan, serta diyakini sebagai tempat mengadu.

2. Tersebarnya filsafat, penyimpangan, dan perdebatan.

3. Tasawuf dan tarekat-tarekat sufi yang sesat menguasai orang-orang awam. Tersebar pula di sana isme-isme dan pemikiran Bathiniyyah.

4. Rafidhah semakin berperan dalam urusan kaum muslimin. Mereka menyebarkan bid'ah dan kesyirikan di tengah-tengah kaum muslimin. Mereka mengendurkan semangat umat untuk berjihad. Bahkan mereka membantu pasukan Tatar yang merupakan musuh kaum muslimin.

5. Pada akhirnya, Ahlusunnah wal Jamaah tidak se-otentik dahulu. Pada saat seperti inilah Ibn Taymiyyah memotivasi dan memberikan semangat kepada Ahlusunnah, guna mengekembalikan ke-otentik-an Ahlussunnah wal Jamaah. Hal ini memiliki pengaruh yang bagus bagi kaum muslimin hingga saat ini dalam menghadapi bid'ah dan kemungkaran, amar ma'ruf nahi munkar, menasihati pemimpin kaum muslimin, dan kaum muslimin secara umum. ${ }^{6}$

Dengan latar belakang kehidupan sosial yang demikian, Ibn Taymiyyah tumbuh dan berkembang. Dan tentu saja hal ini sangat berpengaruh terhadap pemikiran beliau. Karya-karya beliau yang demikian banyak adalah respon terhadap kondisi sosio religius masyarakat pada masanya.

Menurut Nurcholis Madjid, ${ }^{7}$ hanya warisan pemikiran Ibn Taymiyyah yang paling banyak memberi ilham kepada gerakan-gerakan pembaharuan Islam di abad modern. Ia tidak hanya berpengaruh terhadap gerakan Wahabi di jazirah Arabia, tetapi juga kepada gerakan Sanusiyah di Afrika Utara, Muhammad Abduh dan juga pengikut-pengikutnya di seluruh dunia. ${ }^{8}$

\section{Corak Pemikiran Ibn Taymiyyah}

Metodologi yang diusung Ibn Taymiyyah dalam pemikiran dan tulisannya mengenai Tafsir, Akidah, Fiqh dan Tasawuf selalu dikuatkan dengan bukti atau

6 Didi Suryadi AR., “Ibnu Taimiyah: Telisik Metodologi dalam Pemikiran” dalam http:// saungtinta.multiply.com/journal/item/17/IBNU_TAIMIYAH_Telisik_Metodologi_dalam_ Pemikiran (diakses 26 Agustus 2010).

7 Nurcholis Madjid (ed), Khazanah Intelektual Islam. Cet. ke-3, (Jakarta: Bulan Bintang, 1984), hal. 43.

8 Henri Laoust, “Ibn Taymiyyah” dalam Encyclopædia Britannica online:http://www. britannica.com/EBchecked/topic/280847/Ibn-Taymiyyah (Diakses 18 Agustus 2010) 
dalil dari Alquran dan sunnah, kemudian mendekatkan sunnah dengan nalar. Beliau menggunakan dan menentukan nalar hanya sekedar sebagai nasihat bukan untuk gubahan, dan pendekatan bukan untuk petunjuk. Oleh karena itu, kita akan menemukan sebuah kesatuan sifat, tanda dan kepribadian yaitu kesatuan dalam satu metodologi saja.

Metodologi yang ditempuh Ibn Taymiyyah terdiri dari empat unsur:

1. Ibn Taymiyyah tidaklah menggunakan nalar sebagai sumber yang mutlak dalam menentukan hukum, karena, menurutnya, nasòsò tidak mungkin bertentangan dengan aql dan posisi aql harus mengikuti nasòsò tidak seperti mutakallimin yang lebih mengutamakan aql dari pada nasòsò.

2. Ibn Taymiyyah tidaklah berpihak hanya pada satu pendapat saja, bagi Ibn Taymiyyah tidak seorang pun memiliki kebenaran mutlak, melainkan harus berpijak pada Alquran, Sunnah dan Atsar para ulama salaf yang mengikuti Nabi saw. Tentang madzhab empat, Ibn Taymiyyah mengatakan bahwa jika pendapat-pendapat ulama Salaf sesuai dengan Alquran, Sunah dan Atsar, mereka perlu kita ikuti, dan begitu juga sebaliknya.

3. Ibn Taymiyyah berpandangan bahwa Syari'ah itu bersumber dari Alquran, nabi Muhammadlah yang menjelaskan dan memperaktekkannya kepada umat terlebih kepada para shahabat pada masa Nabi saw. Sehingga bagi orang yang mengikuti Nabi saw. melalui tafsir, penjelasan, dan penyampaian para shahabat berarti merekalah sejatinya orang-orang yang mengikuti syari'at Allah dari nabi Muhammad saw. merekalah (para Sahabat) yang menjaga ajaran Nabi saw. karena mereka yang langsung mendengar dan memahami Syari'at Allah langsung dari Nabi saw. begitupun para Tabi'in yang mendapatkan penyampaian dan pemahaman langsung dari para sahabat.

4. Ibn Taymiyyah bukanlah orang yang fanatik terhadap pemikirannya saja, Ibn Taymiyyah selalu melepas dirinya dari segala apa yang mengikatnya, kecuali yang sesuai dengan Alquran, Sunnah dan Atsar Salaf. Ibn Taymiyyah tumbuh dalam madzhab Hambali, akan tetapi Ibn Taymiyyah dapat mengontrol diri, sehingga beliau pun mempelajari dan memperdalam madzhab-madzhab secara keseluruhan, kemudian menghubungkan semua dalam satu sumber. ${ }^{9}$

9 Didi Suryadi AR., "Ibnu Taimiyah: Telisik Metodologi dalam Pemikiran”. 
Pada aspek epistemologi, pemikiran Ibn Taymiyyah memiliki kesamaan dengan kaum empirisme. Menurut Nicholas Heer, terdapat kesamaan pandangan antara sebagian kaum empiris, seperti David Hume, John Lock, dan John Stuart Mill dengan Ibn Taymiyyah. ${ }^{10}$

Empirisme Ibn Taymiyyah sangat tampak dalam karyanya al-Ra'd alâ alMantiqîn. Beliau memaparkan kelemahan logika sebagai metode dalam memperoleh pengetahuan. Menurut beliau, mantiq (logika), sebagai metode berfikir, tidak dapat dipakai untuk mengkaji obyek-obyek keislaman secara hakiki. Obyek keislaman empiris hanya dapat diketahui melalui eksperimen. Sebelum ia mengkritik metode berfikir secara mantiq, terlebih dahulu beliau menguraikan tentang mantiq menurut ahli mantiq. Sebagai mana diketahui, ilmu pengetahuan hanya ada dalam 2 bentuk: pengetahuan dalam bentuk konsep dan pengetahuan dalam bentuk pembenaran. Masing-masing bentuk pengetahuan itu dapat bersifat aksiomatik dapat pula bersifat teoritis. Jika kedua pengetahuan bersifat teoritis, diperlukan metode untuk memperolehnya. Metode perolehan pengetahuan konseptual melalui definisi dan perolehan pengetahuan pembenaran melalui sylogisme (al-qiyas). ${ }^{11}$

Definisi menurut ahli mantiq harus tersusun dari 2 lafaz. Satu lafaz Musytarak (sifat yang dimiliki secara bersama-sama dalam satu jenis genus) dan satunya lafazd Mumayyiz (sifatnya yang merupakan ciri khas bagi masing-masing kelompok jenis). Bagian-bagian ini disebut al-Fashl(difference). Kedua sifat itu hendaknya dari sifat zat, yakni sifat yang menunjukan esensi dari suatu obyek yang didefinisikan. Dan diantara sifat zat yang diambil ialah sifat yang terdekat kepada esensi obyek definisi, misalnya manusia adalah hewan yang berfikir. ${ }^{12}$

Menurut Ibn Taymiyyah, dalam membuat definisi para ahli mantiq diharuskan memilih salah satu dari dua hal: pertama, mereka harus mengemukakan segala sifat-sifat musytarak dari suatu obyek yang didefinisikan, atau kedua, mereka tidak perlu mengemukakan segala sifat-sifat itu sama sekali. Jika yang pertama dipilih, mereka harus mengemukakan segala sifat yang meliputi, jasmani yang tumbuh, memiliki indra dan bergerak atas kehendaknya. Atau tidak merasa perlu mengemukakannya semua, dengan alasan, perkataan "hewan" telah mencakup segala sifat itu. Jika demikian, seharusnya perkataan "hewan” pun ditinggalkan dan cukup

10 Lihat: Nicholas Heer, "Ibn Taymiyah's Empiricism" dalam Farhad Kazemi dan R.D. McChesney, A Way Prepared, (New York: New York University Press, 1988), hal. 109-115 hal. 80 .

11 Hamka Haq, Dialog Pemikiran Islam, (Cet. I; Ujung pandang: Yayasan al Ahkam, 1995),

12 Ibid. 
dengan perkataan "berfikir" saja karena perkataan itu telah mencakup segala sifatsifat "hewan”. Sehingga menurutnya, diwajibkannya menyebut sifat jenis terdekat dalam definisi adalah kesewenangan ahli mantiq dengan menetapkan definisi sempurna melalui metode tersebut diatas. ${ }^{13}$

Ibn Taimiyyah memberi contoh, ahli mantiq mengakui bahwa akal tidak dapat didefinisikan, tetapi kenyataannya mereka mengenal akal. Hal itu menjadi bukti bahwa suatu konsep dapat saja diperoleh tanpa definisi, seperti halnya konsep tentang akal. Lebih lanjut, menurut beliau, untuk membenarkan suatu definisi kepada orang lain, hanya ada dua jalan: Pertama, dibenarkannya berdasarkan pengetahuan yang telah ada tentang obyek definisi, yang ternyata sesuai dengan definisi itu. Ini berarti diketahuinya obyek itu sebelum definisi itu ada. Kedua, dibenarkannya definisi itu tanpa pengetahuan sama sekali mengenai obyek definisi, ini berarti dibenarkannya suatu pernyataan yang belum diyakini kebenarannya. Yang terakhir tidak sepatutnya terjadi, karena sipembuat definisi bukanlah orang yang terlepas dari kesalahan. Pengetahuan mengenai validitas definisi itu sendiri tidak mungkin diperoleh tanpa mengetahui obyeknya terlebih dahulu, sebab definisi itu tidak lebih dari pernyataan yang harus diuji, apakah sesuai atau tidak dengan obyeknya. Antara validitas definisi dengan obyeknya terjadi saling ketergantungan yang bersifat antagonistik, yang satu menentukan yang lainnya. Ini sekaligus menunjukkan rancunya definisi dalam mantiq. Menurut Ibn Taymiyyah, sipembuat definisi itu sendiri, sebelum menyusun definisi sudah tentu telah mengetahui obyek yang akan didefinisikan. Ia mengetahuinya, mungkin dengan suatu definisi sebelumnya, atau mungkin juga diketahuinya tanpa definisi sama sekali. Kalau kemungkinan pertama, maka terjadi definisi yang tidak akan berakhir (tasalsul). Atau kemungkinan kedua, maka suatu obyek dapat saja diketahui tanpa definisi. Jika kemungkinan, maka pernyataan "suatu obyek tidak diketahui kecuali dengan definisi” menjadi batal. ${ }^{14}$

Dari uraian di atas, dapat dipahami kritikan Ibn Taymiyyah terhadap logika Aristoteles mengenai defiinisi sebagai Pergenus et Differentia serta teori silogismenya, dengan argumen bahwa pengetahuan tidak bisa dibatasi pada penalaran silogistik saja. Penalaran deduktif hanya merupakan kegiatan intelek dan tidak ada hubungannya dengan realitas fisik yang sebenarnya. Maka penalaran deduktif tidak

13 Ibid., hal. 82 Uraian lengkap tentang kritikan Ibn Taymiyyah terhadap sillogisme mantiq dapat dilihat dalam Ibn Taymiyyah, Naqdh al-Mantiq, (Cet. I; Kairo: Mathba'ah al-Sunnah alMuhammadiyyah, 1370 H./1951 M.), hal. 200-211

14 Hamka Haq, ibid.,hal. 86 
bisa menghasilkan pengetahuan yang berguna, harus empiris dan faktual, dengan kata lain harus induktif bukan deduktif. ${ }^{15}$

Singkat kata, posisi Ibn Taymiyyah menegaskan bahwa segenap pengetahuan ihwal dunia eksternal dihasilkan dari hasil observasi atas hal-hal partikular. Proposisi-proposisi universal disimpulkan melalui analogi atau induksi dari proposisi-proposisi partikular, dan jika memang benar bahwa analogi dan induksi menghasilkan hanya pengetahuan yang bersifat mungkin, maka pengetahuan kita tentang dunia eksternal, kecuali yang terkandung dalam kitab suci, hanyalah bersifat mungkin dan tidak pasti.

Orang dapat saja mengakui John Lock (1632-1704) David Hume (1711-1776 M) serta pemikir empiris Barat lainnya memiliki hasil pemikiran yang orisional, tetapi hal itu tidak dapat menghapus sama sekali dugaan bahwa mereka itu mungkin menerima pengaruh dari pemikiran Ibn Taymiyyah atau setidak-tidaknya mereka pernah menelaah karya-karyannya. ${ }^{16}$

Selain itu pula harus diakui jasa Ibn Taymiyyah dimana kritikan-kritikannya terhadap logika tradisional melahirkan logika modern dan masih berlaku hingga kini. Logika Aristotelean yang dikritik tampaknya dengan tujuan untuk meratakan jalan bagi iman, sebab apabila alat pemikiran rasional dapat dibuktikan kelemahanya, hasil-hasilnya tidak perlu dipertimbangkan dan dengan sendirinya akan ditolak. ${ }^{17}$

Karakter empirisme inilah yang mewarnai pemikiran Ibn Taymiyyah, sehingga karya-karya intelektualnya selalu berangkat dari realitas, termasuk dalam membaca makna kitab suci yang cenderung tekstual dan menghindari takwil. Bila kita mencermati karya-karya beliau, dapat dilihat beberapa tema sentral yang digusungnya, yaitu: pertama, seruan untuk kembali kepada Alquran dan Sunnah, yang sekaligus mendasari seluruh ide dan proyek intelektualnya. ${ }^{18}$ Kedua, menegakkan faham tauhid secara benar dan lurus, beliau menyatakan perang terhadap kemusyirikan, bid'ah dan sufisme populer. ${ }^{19}$ Ketiga, mengikuti kaum salaf, khususnya generasi sahabat,

15 C.A. Qadir, Philosiphy and Science in The Islamic World, diterjemahkan oleh Hasan Basari dengan judul : Filsafat dan Ilmu Pengetahuan dalam Islam, (Cet. I; Jakarta: Yayasan Obor Indonesia, 1989), hal. 145

16 Hamka Haq, Dialog...,hal. 101

17 C.A. Qadir, Philosiphy..., hal. 145

18 Lihat: Ibn Taymiyyah, Naqdh al-Mantiq, hal. 57-58; Mansur Muhammad Muhammad 'Uwais, Ibn Taymiiyyah Lais Salafiyyan, (Cet. I; Beirut: Dâr al-Nahdhah al-'Arabiyyah, 1970), hal. 27

19 Lihat: Ibn Taymiyyah, Rasâ’il wa Masâ’il Ibn Taymiyyah, Juz I, (t.tp.: Dâr al-Nasyr, t. th.), hal. 42 
tabi'in dan tabi' tabi'in. Keempat, membuka kembali pintu ijtihad, dan inilah yang menjadi spirit gerakan pembaharuan yang mengilhami banyak tokoh sesudahnya.

\section{Gagasan Ijtihad Ibn Taymiyyah}

Masalah tertutup atau terbukanya pintu ijtihad mutlak, bagi Ibn Taymiyyah bukan masalah yang mendasar, karena ia tidak meresponnya secara serius. Baginya, taklid dibolehkan bagi mereka yang tidak mampu dalam batas-batas yang dibenarkan syariat, dan ijtihad dibolehkan bagi setiap orang yang memiliki kemampuan untuk itu, terlepas apakah itu ijtihâd mutlaq atau ijtihâd nisbî.

Berbeda dengan ulama yang tidak membenarkan seorang mujtahid bertaklid kepada mujtahid lain, Ibn Taymiyyah malah membolehkannya selama ada alasan tertentu yang dapat dibenarkan, seperti karena waktu yang mendesak, kesulitan mencari dalil, atau dalil yang sama-sama kuat, dan sebagainya. Menurutnya, ijtihad bukan masalah yang harus dimonopoli oleh seorang dan tidak dapat dibagi-bagi. Bahkan, seorang mujtahid dapat mengadakan ijtihad terhadap suatu masalah tertentu, bukan pada masalah yang lain.

Ibn Taymiyyah bahkan menganggap terpuji terhadap seseorang yang pindah dari satu pendapat kepada pendapat lain yang lebih kuat. Mengikuti pendapat yang tidak memiliki alasan dan meninggalkan pendapat lain yang jelas kehujjahannya merupakan sikap tercela. Begitu pula dengan peralihan kepada suatu pendapat karena pertimbangan tradisi atau kecenderungan hawa nafsu.

Jika ada masalah yang dipertentangkan, sebaiknya melakukan penelitian terlebih dahulu terhadap semua pendapat yang ada kemudian baru menentukan pilihan kepada pendapat yang kebenarannya lebih mendekati Alquran dan Sunnah, seraya tetap memberikan kebebasan kepada setiap orang untuk memegang salah satu dari pendapatpendapat itu. Selain itu, boleh pula melakukan ijtihad, memberi fatwa dan menetapkan hukum mengenai masalah yang belum ada ketentuan hukumnya oleh ulama. Di sini tampak bahwa ia berbeda dengan Ibn Hanbal yang cenderung melarang melakukan ijtihad semacam itu. Ibn Hanbal berkata, "Hindarilah membicarakan (hukum) suatu masalah yang tidak kamu jumpai seorang imam pun (yang menetapkannya). ${ }^{20}$

Oleh sebab itu, kata Ibn Taymiyyah, untuk menghindari kemungkinan terjadinya taklid berlebihan, semenjak dini para tokoh Islam telah mengingatkan untuk tidak begitu saja mengikuti mereka. Abû Bakr al-Siddîq tidak pernah menyuruh

20 Ahmad b Muhammad b 'Abd al-Ghanî, al-Musawwadah fî̀ Usûl al-Fiqh, (Mesir: Matba'ah al-Madanî, t.th), hal. 543. 
umat Islam mengikutinya tanpa reserve. Mâlik menolak permintaan Hârûn alRashîd yang ingin menjadikan kitabnya al-Muwatta' sebagai pedoman umat saat itu. Begitu pula yang terjadi pada Abû Hanîfah, al-Shâfî̀̂, dan Ahmad b. Hanbal.

Menurut Ibn Taymiyyah, setiap muslim pada dasarnya berkewajiban untuk taat kepada Allah dan Rasul-Nya selain patuh kepada $\hat{u} l \hat{i}$ al-amr, selama tidak memerintahkan maksiat, dan wajib menjadikan Alquran dan Hadis sebagai dasar hukum yang harus diikuti dipedomani. Mereka wajib mengimani kebenaran teksteks itu, meskipun tidak mengetahui hakikat makna yang terkandung didalamnya. Terhadap hasil ijtihad para ulama, seorang bebas memilih antara menerima dan menolak. Kalau pendapat itu sesuai tuntunan Nabi, boleh diterima dan diikuti. Sebaliknya, mereka wajib menolaknya jika jelas-jelas menyalahi tuntunan Rasul Saw.

Ibn Taymiyyah tidak menganggap ijtihad sebagai kegiatan yang tidak bisa dijangkau oleh para ahli fikih sepeninggal imam-imam mujtahid. Ia pun tidak bermaksud menjadikan ijtihad sebagai suatu yang amat mudah yang bisa dilakukan oleh siapa saja. Bahkan ia tidak setuju dengan pendapat yang mengharuskan ijtihad kepada setiap orang meskipun dalam masalah-masalah furû' sekalipun. Ia mengajukan sejumlah persyaratan seorang mujtahid. ${ }^{21}$ Ibn Taymiyyah juga setuju dengan para ulama lain yang mengelompokkan tingkatan mujtahid: mujtahid mustaqill dan mujtahid muntasib. ${ }^{22}$

\section{E. Sumber Hukum Ijtihad Ibn Taymiyyah}

Berdasarkan penelitian terhadap usûl al-fiqh Ibn Taymiyyah oleh Sâlih b. 'Abd al-Azîz, ${ }^{23}$ Muhammad Yûsuf Mûsâ, ${ }^{24}$ dan Abû Zahrah, ${ }^{25}$ fatwa-fatwa Ibn Taymiyyah umumnya didasarkan pada:

21 Di antara syarat terpenting yang harus dimiliki setiap mujtahid, menurut Ibn Taymiyyah, adalah penguasaan bahasa Arab, usûl al-fiqh dan hadis beserta seperangkat ilmunya. Lihat Ibn Taymiyyah, Iqtidâ’ al-Sirât al-Mustaqîm Mukhâlafah Ahzâb al-Tahîm, (Beirut: Dâr al-Fikr, t.th.), hal. 207.

22 Menurutnya, mujtahid mutlaq adalah yang sanggup mandiri dalam menggali hukumhukum syariat dari dalîl shar'î (Alquran dan Hadis) tanpa taklid dan terikat dengan pendapat orang lain, sementara mujtahid muntasib adalah kebalikannya. Lihat Abd al-Ghanî, al-Musawwadah, hal. 546.

23 Lihat Sâlih b. 'Abd al-Azîz 'Alî Mansûr, Usûl al-Fiqh wa Ibn Taymiyyahal. Jilid 2, (t.p., t.t., t.th.), hal. 671 .

24 Lihat Muhammad Yûsuf Mûsâ, Ibn Taymiyyahal. (Mesir: Maktabah al-Misr, tth), hal. 168.

25 Lihat Abû Zahrah, Ibn Taymiyyah, hal. 453. 


\section{Alquran}

Ibn Taymiyyah menempatkan Alquran sebagai sumber hukum yang pertama. Alquran dan Hadis mencakup sebagian besar atau seluruh hukum yang berhubungan dengan perilaku manusia. Alquran dan Hadis berbicara dengan menggunakan kalimat yang sifatnya konprehensif dan umum sebagai keputusan atau proposisi universal (qadiyyah kulliyah) dan kaidah-kaidah umum yang mencakup berbagai genus dalam jumlah banyak. ${ }^{26}$

Sebagai contoh, kata Ibn Taymiyyah, Allah mengharamkan khamr dalam Alquran. ${ }^{27}$ Sebagian besar orang menduga khamr pada kedua ayat tersebut hanya mengacu kepada 'asîr al-inab (perasan anggur) semata-mata, sehingga tidak mengharamkan minuman keras lain seperti pendapat fuqahâ’ Kufah. Para fuqahâ' Irak, seperti Ibrâhîm al-Nakhâ'î, Sufyan al-Thawrî, Ibn Abî Laylâ, Shârik, Ibn Shubrumah, dan Abû Hanîfah, para fuqahâ’ Kufah dan umumnya ulama Basrah, berpandangan bahwa semua perasan anggur (minuman) yang diharamkan itu karena unsur memabukkannya, bukan karena zatnya. ${ }^{28}$

Menurut Ibn Taymiyyah, kata khamr yang disebutkan dalam Alquran karena berdasarkan teks umum (al-nass al-âm) dan kalimat menyeluruh (al-kalimah aljâmi’ah) mencakup semua bentuk dan jenis makanan dan minuman memabukkan yang jumlahnya jauh lebih banyak.

\section{Hadis Nabi}

Setiap muslim yakin bahwa Hadis adalah hukum kedua setelah Alquran. Bahkan Ibn Hanbal menempatkan Hadis, yang ini membedakannya dengan Ibn Taymiyyah, sebagai hukum Islam pertama bersama Alquran. Ibnu Taymiyyah menolak secara tegas kebolehan menghapus (hukum) Alquran dengan Hadis (naskh al-Qur'ân bi al-Sunnah) yang dianut oleh umumnya ulama, termasuk Ahmad b. Hanbal. Ia tidak meletakkan hadis dalam posisi yang sama, karena dalam banyak hal, Hadis berbeda dengan Alquran, meskipun dalam beberapa segi tertentu keduanya memiliki persamaan.

Selain membedakan Hadis dari segi dalâlah (qat'î dan zannî), Ibn Taymiyyah membagi Hadis dari segi penyampaiannya kepada tiga bagian: pertama, sebagai

26 Ibn Taymiyyah, Rasầil, Juz I, hal. 336

27 Q.S. al-Baqarah [2]: 219; al-Mâ'idah [9]: 90.

28 Muhammad b. Ahmad Ibn Rushd, Bidâyat al-Mujtahid wa Nihâyat al-Muqtasid, Jilid 1, (Mesir: Mustafâ al-Bâbi al-Halabî, 1960), hal. 471. 
penafsir, misalnya hadis-hadis yang berkenaan dengan zakat, haji, umrah dan lain-lain. Tentang Hadis ini, telah ada kesepatakan ulama untuk menerimanya sebagai hujjah. Kedua, Hadis mutawatir yang tidak menafsirkan zahir teks Alquran atau menyalahi zahir Alquran karena mendatangkan hukum baru yang tidak ada dalam Alquran, seperti hadis penentuan nisab. Ahli fikih menerima kehujjahan hadis kelompok kedua ini, kecuali kaum Khawârij. Ketiga, hadis âhâd yang penyampaiannya melalui riwayat yang thiqah, memenuhi syarat yang ditentukan para muhaddith. Kehujjahan hadis ini telah diakui para ahli fikih, ahli hadis, ahli tasawuf dan umumnya ulama, kecuali sebagian ahli kalâm yang menerima sebagian dan menolak sebagian berdasarkan syarat-syarat tertentu yang mereka buat. ${ }^{29}$

\section{Ijmâ'}

Ibn Taymiyyah menempatkan ijmâ' sebagai sumber hukum ketiga setelah Alquran dan Hadis. Ini bukan tanpa alasan. Ia merujuk kepada athâr para Sahabat Nabi Saw, diantaranya 'Umar b. al-Khattâb yang pernah berkata kepada Shuraih:

"Putuskanlah (perkara itu) menurut hukum yang ada dalam kitab Allah. Kalau tidak ada (dalam Alquran), putuskanlah sesuai dengan hukum yang ada dalam Sunnah Rasul Saw. Jika tidak ada (dalam Sunnah Rasul), putuskanlah berdasarkan hukum yang telah disepakati oleh (umat) manusia." Dalam riwayat lain, "putuskanlah menurut hukum yang telah ditetapkan oleh orang-orang saleh. ${ }^{30}$

Menurut pengertian Ibn Taymiyyah, Ijmâ' adalah "kesepakatan para ulama mengenai suatu hukum dari beberapa hukum”. Ibn Taymiyyah membagi Ijma’ ke dalam dua macam: ijmâ' qat'î dan ijmâ' zannî. Ijmâ' qat'î adalah ijmâ' yang dinukilkan secara mutawatir, baik ucapan maupun perbuatan, atau ijma'yang telah dipastikan tidak ada yang menyalahi keberadaannya, yang disandarkan pada teks Alquran dan Hadis. Apabila telah ada ketetapan ijmâ' umat yang qat'î terhadap hukum suatu masalah, maka, menurut Ibn Taymiyyah, tidak seorang pun boleh meninggalkan-dianggap sebagai orang yang menempuh jalan selain jalan orang beriman yang dicela Alquran ${ }^{31}$-ketetapan ijmâ' tersebut. Karena, tidak mungkin umat Islam menyepakati sesuatu masalah atas dasar kesesatan.

29 Lihat:Ibn Taymiyyah, Rasâ’il, Juz II, hal. 153-155

30 Lihat 'Abd al-Ghanî, al-Musawwadah, hal. 316.

31 Lihat Q.S. al-Nisâ' [4]: 115. 
Uraian di atas memberikan indikasi bahwa betapa kuatnya Ibn Taymiyyah berpegang kepada ijmâ'sebagai dasar hukum. Bersamaan dengan itu, ia amat hatihati dan membatasi diri dalam penggunaan ijmâ’. Ia mensyaratkan ijma’: 1) harus benar-benar merupakan kesepakatan seluruh ulama dalam masa tertentu, atau dalam suatu kota tertentu, kecuali kota Madinah pada masa sahabat. Syarat lain yang ditetapkan Ibn Taymiyyah adalah ijmâ itu; 2) harus berlandaskan pada nasòs baik Alquran maupun Hadis.

Mengingat syarat pertama begitu berat, maka Ibn Taymiyyah menyadari betapa sulit ijma' semacam itu dapat terwujud. Karena itu, ia berpendapat bahwa ijma' hanya mungkin terjadi pada masa-masa sahabat, sulit untuk generasi setelah mereka walaupun tidak berarti mustahil terjadi. Sehubungan dengan hal itu, Ibn Taymiyyah mengkritik pendapat sebagian orang yang menganggap ijma'sebagai dasar bagian terbesar hukum-hukum syari'at, bahkan dianggap tidak memiliki pengetahuan tentang Alquran dan Hadis.

Ibn Taymiyyah juga mengambil fatwa-fatwa sahabat dalam mengistinbatkan hukum jika ia tidak menjumpai nass dan ijmâ’. Mengenai pendapat para sahabat (aqwâl al-Sahâbah), Jumhur ulama memandangnya sebagai hujjah kalau pendapat dimaksud tersebar luas dan tidak diingkari oleh sahabat lain pada masa mereka. Di samping itu, Ibn Taymiyyah juga berpegang pada pendapat tâbi'în dan tâbi’ altâbi'în yang sesuai dengan Alquran dan Hadis jika ia tidak menemukan dalil hukum yang telah disebutkan terdahulu.

\section{Qiyâs}

Ibn Taymiyyah juga menerima qiyâs sebagai dasar hukum. Qiyâs dipahaminya sebagai "menghimpun dua masalah yang serupa dan membedakan dua masalah yang berbeda." ${ }^{2}$ Ibn Taymiyyah membagi qiyâs dalam dua macam: al-qiyâs al-sahîh dan al-qiyâs al-fâsid. Kedua jenis qiyâs inilah yang digunakan para sahâbah dan tâbi'în dalam menetapkan hukum secara pasti dalam Alquran, Hadis dan Ijmâ'. Di antara bentuk qiyâs fâsid yang menyalahi dalâlat al-nass adalah meng-qiyâs-kan dua masalah yang masing-masing dihalalkan dan diharamkan oleh nass seperti menganalogikan orang-orang yang menyamakan jual beli dengan riba dengan dasar sama-sama mencari keuntungan. Padahal, dengan tegas nass mengharamkan riba dan menghalalkan jual beli.

32 Ah?mad Ibn Taymiyyah dan Ibn al-Qayyim al-Jawziyyah, al-Qiyâs fî al-Shar' al-Islâmî, (Beirut: Dâr al-Âfâq al-Jadîdah, 1982), hal. 10 
Ibn Taymiyyah berpendirian bahwa tak ada satupun qiyâs sahîh yang menyalahi nass. Karenanya, 'illat hukum tidak harus selalu berupa sifat yang tampak, akurat atau tepat dan relevan (wasf zâhir mundabit munâsib), namun 'illat terkadang berbentuk sifat yang relevan (wasf munâsib) atau hikmah yang mendorong disyariatkanya suatu hukum. Seluruh nass syari'at tentunya di-'illat dengan maslahah dan menolak mafsadah, terlepas dari persoalan apakah ia mundabitah atau tidak. Jika pembinaan qiyâs atas dasar maslahah mu'tabarah dapat diterima, maka pembentukan qiyâs atas dasar hikmah juga bisa diterima, mengingat hikmah itu pada hakikatnya merupakan bagian tak terpisahkan dari maslahah secara umum.

\section{Tahap-tahap Perkembangan Ijtihad Taymiyyah}

Proses perkembangan ijtihad Ibn Taymiyyah dalam bidang hukum Islam pada dasarnya dapat dibedakan dalam tiga fase:

- Ibn Taymiyyah umumnya terikat dengan fikih ulama Hanbalî, dan khususnya fikih Ahmad b. Hanbal.

- Kemudian, ia mulai mengadakan pembahasan yang mendalam kepada hampir seluruh mazhab fikih yang ada, terutama mazhab yang empat. Setelah itu, ia melakukan komparasi antara satu dengan lainnya untuk memilih pendapat yang lebih kuat (arjah). Selanjutnya, mengambil pendapat yang menurut penilaiannya lebih dekat kepada Alquran, Hadis dan Athâr al-Sahâbah. ${ }^{33}$

- Terakhir, ia melakukan ijtihad secara mandiri, langsung memahami teks-teks Alquran dan Hadis dengan memperhatikan tujuan umum syariat (maqâsid alsharî̉ah al-âmmah). Tanpa terikat dengan mazhab tertentu, termasuk mazhab Hanbali, Ibn Taymiyyah menyampaikan fatwa-fatwanya dengan bebas, meskipun sebenarnya tidak keluar dari konteks pendapat mazhab-mazhab yang telah ada, terutama mazhab empat. Pada tahap terakhir inilah, Ibn Taymiyyah kerap menyampai-kan fatwa-fatwanya yang berbeda dengan pendapat imam-imam terkenal, bahkan oleh sebagian ulama Islam dinyatakan sebagai keluar dari ijmâ' umat Islam. ${ }^{34}$

33 Muhammad Husnî al-Zayn, Mantiq Ibn Taymiyyah wa Manhajuhu al-Fikrî, (Beirut: alMaktabah al-Islâmiyyah, 1979), hal. 350.

34 Lihat Muhammad Bahjah al-Baytar, Hayât Shaykh al-Islâm Ibn Taymiyyah, (Beirut: alMaktabah al-Islâmiyyah, t.th.), hal. 45. 


\section{F. Beberapa Contoh Ijtihad Ibn Taymiyyah}

Dalam pembahasan yang lalu, telah dijelaskan kemandirian Ibn Taymiyyah dalam berijtihad, yang tidak terikat dengan pendapat mazhab tertentu, bahkan terkadang menyalahi pendapat jumhûr al-fuqahâ'. Berikut akan dikemukakan beberapa contoh hasil ijtihad Ibn Taymiyyah, terutama yang menyalahi umumnya fuqahâ' (mazhab empat).

\section{Masalah Ibadah}

\section{Sujud Tilâwah tanpa Wudû' Hukumnya Sah}

Menurut kebanyakan fuqahâ', hukum mengerjakan sujud tilâwah adalah sunnah. Namun, Abû Hanifah konon menyatakan wajib meskipun bukan fardu. Menurut ulama Hanafiyyah, akan berdosa orang yang tidak melakukan sujud tilâwah pada saat ia membaca atau mendengar ayat sajdah. ${ }^{35}$ Sementara itu, umumnya ahli fikih mengidentifikasikan sujud tilawah dengan shalat, dan karenanya mereka menyamakan persyaratan sujud tersebut dengan persyaratan yang berlaku untuk shalat, seperti menghadap kiblat, menutu aurat dan suci dari hadas serta harus berwudu. ${ }^{36}$

Berbeda dengan jumhûr fuqahâ', Ibn Taymiyyah membedakan antara sujud tilawah dengan shalat, bahkan dengan tegas ia menyatakan bahwa sujud tilâwah itu bukan shalat. Oleh karena itu, yang diharuskan dalam mengerjakan shalat tidak mesti diharuskan dalam sujud tilâwah. Maka, Ibn Taymiyyah menyatakan melakukan sujud tilawah tanpa wudu hukumnya tetap sah. Namun, yang utama adalah jika dikerjakan sesuai syarat-syarat yang berlaku dalam shalat, termasuk keharusan berwudu. ${ }^{37}$

Tidak ada ketentuan jarak dan waktu untuk mengerjakan salat qasr dan berbuka puasa bagi musafir

Ulama sepakat tentang kebolehan meng-qasr shalat dan berbuka puasa (iftâr) bagi orang yang berpergian (musâfir), meskipun mereka berbeda pendapat mengenai ketentuan hukum dan batas (jarak) kebolehan mengerjakannya.

35 Abd al-Rahmân al-Jaza'irî, Kitâb al-Fiqh 'alâ al-Madhâhib al-Arba'ah, Jilid 1, (Beirut: Dâr al-Fikr, tt), hal. 464.

36 Lihat: Wahbah al-Zuhayli, al-Fiqh al-Islâmiy wa Adillatuh, Juz II, (Cet. II; Damasqus: Dar al-Fikr, 1985), hal. 120-127

37 Alâ' al-1̂in Abû al-Hasan, al-Akhbâr al-Ilmiyyah min al-Ikhtiyârât al-Fiqhiyyah min Fatâwâ Shaykh al-Islâm Ibn Taymiyyah, (Beirut: Dâr al-Fikr, t.th.), hal. 60. 
Aneka ragam (jarak) tempat dan waktu Rasulullah Saw mengerjakan shalat qasr, dijadikan oleh Ibn Taymiyyah sebagai salah satu alasan untuk tidak memberikan ketentuan yang pasti tentang batas minimal dan batas maksimal dari jarak (masâfah) yang mem-bolehkan qasr shalat bagi musafir. Menurutnya, boleh meng-qasr shalat pada setiap bepergian (safar), apakah itu perjalanan relatif dekat maupun jauh. Ia menambahkan, tidak perlu memberi ketentuan secara pasti tentang jarak dibolehkannya meng-qasr shalat dalam safar, karena Nabi sendiri tidak pernah menetapkannya. ${ }^{38}$

Namun, Ibn Taymiyyah juga mengingatkan tentang pentingnya batasan berpergian yang menurut adat kebiasaan dianggap sebagai safar, seperti perlunya membawa perbekalan dan keluar daerah yang relatif jauh. Sedangkan bepergian yang tidak perlu menyiapkan perbekalan karena jaraknya relatif dekat tidak dapat dikatanan musafir, dan karenanya ia tidak dibenarkan melakukan qasr shalat. Sama halnya, Ibn Taymiyyah juga tidak membenarkan penentuan batas minimal kebolehan iftâr puasa bagi musafir. Pendapat Ibn Taymiyyah yang tidak membenarkan penentuan batas jarak dan waktu safar yang menyebabkan musafir boleh mengqasr shalat dan melakukan iftâr tampak menyalahi pendapat jumhûr al-fuqahâ, namun sesuai dengan pendapat Dâwûd al-Zâhirî yang dalam banyak hal sering dikritik oleh Ibn Taymiyyah. ${ }^{39}$

Sebagian orang menilai pendapat Ibn Taymiyyah yang tidak menentukan batas minimal masâfah al-qasr dan iftâr bagi musafir lebih sesuai dengan zahir ayat yang mensyariatkan shalat qasr dan iftâr itu sendiri (Q.S. al-Nisâ’ [4]: 101; Q.S. al-Baqarah [2]: 184). Zahir ayat yang berkaitan dengan kedua hal tersebut memang bersifat mutlak, dalam pengertian, shalat qasr dan iftâr puasa dalam safar itu tidak dibatasi oleh jarak dan waktu tertentu. Berkenaan dengan itu, Ibn Taymiyyah menyatakan: "Sesuatu yang oleh Shâri' dimutlakkan penggunaannya, harus dimutlakkan pula penamaan dan realisasinya. Tidak boleh mengira-ngira dan membatasinya dengan masa (waktu) tertentu." ${ }^{40}$

Pendapat Ibn Taymiyyah ini agaknya relevan jika dikaitkan dengan perkembangan dunia yang semakin maju di bidang transportasi. Hendaknya mempertimbangkan jenis kendaraan yang dipakai seorang musafir dalam

38 Ibid., hal. 72.

39 Lihat: Ibn Taymiyyah, Rasâ'il, Juz I, hal. 223-226

40 Dikutip dalam Ibid., hal. 73. 
perjalanannya. Unsur mashaqqah yang dialami secara berbeda-beda oleh masingmasing musafir karena perbedaan fisik tampaknya memang lebih penting diperhatikan ketimbang hanya sekedar soal jarak dekat atau jauhnya suatu perjalanan.

Tidak batal puasa orang, yang karena lupa atau yakin berada pada malam hari, mengerjakan hal-hal yang membatalkan puasa

Menurut mayoritas fuqahâ', orang puasa yang makan atau minum karena lupa, kesalahan, atau dipaksa, puasanya tetap sah, tidak perlu qadâ' dan kaffârah. Ibnu Taymiyyah sependapat dengan hal ini. Selanjutnya, menurut jumhur ulama, termasuk empat imam mazhab fikih, orang puasa yang makan, minum atau bersetubuh karena menduga atau bahkan yakin matahari telah terbenam (malam) atau menganggap fajar belum terbit, puasanya dinyatakan batal dan karenanya harus meng-qada'nya, jika ternyata keadaan menunjukkan sebaliknya, yakni, yakin sudah terbih fajar atau matahari belum terbenam.

Di sini, Ibn Taymiyyah berbeda dengan jumhur. Ibn Taymiyyah menyatakan orang yang makan pada siang hari di bulan Ramadan karena berkeyakinan telah atau masih malam, maka puasanya tetap sah, meskipun kemudian ternyata sudah atau masih siang. Menurutnya, orang tersebut tidak perlu meng-qadâ' puasanya. Demikian pula orang yang bersetubuh pada siang hari di bulan Ramadhan karena lupa atau tidak tahu. ${ }^{41}$ Pendapat ini didasari pada Q.S al-Ahzâb [33]: 5, al-Baqarah [2] 187, dan juga Hadis Nabi Saw dari Ibn Abbas. ${ }^{42}$

Dalam surat al-Baqarah: 187 ini, kata Ibn Taymiyyah, Allah membolehkan seseorang makan, minum dan jimâ'(pada malam hari ramadhan) sampai terbit fajar, sementara di lain pihak Allah juga mengajurkan supaya mengakhiri makan sahur. Orang yang mengerjakan hal yang dianjurkan dan dibolehkan, dalam hal ini makan, minum dan jimâ' di penghujung (akhir) malam, tidak tepat dianggap sebagai melampaui batas apabila di luar kesengajaannya ternyata sudah siang (terbit fajar). Kasus demikian, tambah Ibn Taymiyyah, merupakan kesalahan (tidak disengaja) yang sifat uzurnya melebihi orang yang lupa. Sedangkan Allah memaafkan tindakan seseorang yang dilakukan karena lupa atau tidak sengaja.

41 Ibid., hal. 109.

42 "Sesungguhnya Allah telah membebaskan (dari dosa) umatku (yang dilakukan) karena kesalahan dan kelupaan, serta yang dipaksakan (pihak) lainnya kepadanya.” (HR. Ibn Mâjah, al-Tabrânî, al-Hakîm). 


\section{Masalah Muâmalah}

\section{Menjatuhkan tiga talak sekaligus hukumnya jatuh satu.}

Di kalangan ulama terdapat perbedaan pendapat mengenai hukum penjatuhan tiga talak sekaligus. Sebagian kaum Mu'tazilah dan Shî’ah menyatakan tidak jatuh sama sekali. Sedangkan mengenai beberapa talak yang harus dianggap jatuh, terjadi perbedaan pendapat. Selain sahabat Nabi, umumnya Tâbi'în dan imam-imam mazhab empat menyatakan jatuh tiga, sedangkan sebagian yang lain berpendapat hanya satu. Sementara itu, ada yang menyatakan jatuh tiga jika wanita yang ditalak itu telah pernah digauli, dan hanya dihitung satu jika ternyata belum pernah digauli.

Ibn Taymiyyah memilih pendapat kedua yang menganggap penjatuhan tiga talak sekaligus hukumnya hanya jatuh satu. Pendapat ini sama dengan pendapat alZâhirî, yang juga merupakan pendapat sebagian sahabat, seperti Zubair b. al-'Awwâm dan 'Abd al-Rahmân b. 'Auf, dan juga menurut sebagian riwayat, pendapat 'Alî b. Abî Tâlib, Ibn Mas'ûd dan Ibn 'Abbâs. ${ }^{43}$

Seperti jumhur fuqahâ', Ibn Taymiyyah menilai pendapatnya sesuai dengan ayat Alquran (al-Baqarah [2]: 229) dan Sunnah. Ungkapan al-talâq marratâni dalam ayat tersebut mengandung maksud untuk tidak menjatuhkan tiga talak sekaligus, namun harus sekali demi sekali, karena Allah berfirman al-talâq marratâni, bukan al-talâq talqatâni. Dengan demikian, kata Ibn Taymiyyah, jika seorang suami berkata kepada isterinya, engkau tertalak dua, tiga, sepuluh, seratus, atau seribu, talak yang jatuh tetap saja satu.

Karena Alquran dan hadis telah mengatur soal penjatuhan talak, yang hukum asalnya dilarang, maka penjatuhan talak yang menyalahi aturan syariat (dalam hal ini, penjatuhan tiga talak sekaligus) tergolong jenis perbuatan yang dilarang, sedangkan melakukan perbuatan yang dilarang hukumnya batil. Jadi, penjatuhan tiga talak sekaligus itu batal karena menyalahi Alquran yang hanya membolehkan penjatuhan talak sekali demi sekali.

Sedangkan, banyak ulama menilai pendapat Ibn Taymiyyah di atas sebagai menyalahi pendapat umumnya ulama Islam, bahkan ada yang menuduhnya keluar dari ijmâ’. Namun, tidak sedikit ulama yang menganggap pendapat Ibn Taymiyyah

43 Ibn Taymiyyah, Majmû’ Fatâwâ Ibn Taymiyyah, Juz 33, (t.tp.: Dâr 'Âlam al-Kutub, t.th.), hal. 5 
justru lebih kuat dari pada pendapat jumhur, seperti diungkapkan oleh al-Shawkânî, Ibn Qayyim al-Jawziyyah, ${ }^{44}$ dan Ibn Hajar al-Asqalânî.

\section{Menukar atau Menjual Harta Wakaf Hukumnya Boleh}

Dasar hukum bagi wakaf adalah hadis riwayat Bukhârî-Muslim dari Ibn 'Umar, yang intisarinya adalah sebagai berikut:

"Kemudian 'Umar mewakafkan hartanya itu dengan pengertian tanahnya itu sendiri tidak boleh dijual, tidak boleh diwariskan dan tidak boleh dihibahkan. 'Umar menyedekahkan hasilnya kepada orang-orang fakir, kaum kerabat, untuk memerdekakan budak untuk jalan Allah, orang terlantar dan para tamu ..." 45

Namun, mengingat harta wakaf itu mungkin bisa berkurang atau habis manfaatnya, baik karena pengelolaan yang tidak memadai maupun karena rusak dimakan usia, maka Ibn Taymiyyah memberi peluang untuk menukar atau menjual harta wakaf itu jika memang dipandang lebih maslahat.

Mengenai wakaf yang berbentuk masjid, selain ulama Hanbalî, para ulama sepakat tentang ketidakbolehan menjual masjid dan menggunakan hasilnya dengan alasan apapun sampai masjid itu rusak sekalipun. Namun, ulama mazhab Hanbalî, termasuk Ibn Taymiyyah, berpandangan bahwa masjid itu boleh dijual jika benarbenar dibutuhkan, seperti karena alasan tidak mungkin lagi bisa dimanfaatkan karena terlalu sempit sehingga tidak mampu menam-pung jama'ah padahal untuk memperluasnya tidak dimungkinkan lagi. ${ }^{46}$

Lebih jauh, Ibn Taymiyyah dan umumnya ulama Hanbalî yang membolehkan menukar atau menjual mesjid dalam kondisi darurat, membolehkan, bahkan menganjurkan, jika itu dipandang lebih baik dan lebih maslahat. Menurut Ibn Taymiyyah, penukaran harta wakaf dilakukan karena dua alasan: pertama, karena diperlukan (hajah), seperti mewakafkan seekor kuda untuk tentara yang sedang berjihad dijalan Allah, kemudian kuda tersebut diperlukan lagi setelah perang usai; kedua, karena kemaslahatan yang lebih besar, seperti menjual mesjid berikut tanahnya yang kurang berguna, kemudian membeli tanah lain dan diatasnya dibangun mesjid baru yang lebih luas dan strategis. Hal ini pernah dilakukan

44 Ibn Qayyim al-Jawziyah, I'lâm al-Muwaqiîin 'an Rabb al-'Âlamîn, Jilid 2, (Beirut: Dâr alJalîl, t.th.), hal. 34-35.

45 Dikutip dalam Ibn Hajar al-‘Asqalânî, Bulughul Maram, Terj. Ahmad b. Sa’ad b. Nabhan, (Surabaya: tp., tth.), hal. 191.

${ }^{46}$ Muhammad Jawâd Mughniyyah, al-Ahwâl al-Shakhsiyyah 'alâ al-Madhâhib al-Khamsah, (Beirut: Dâr al-'Ilm li al-Malayîn, 1964), hal. 329. 
'Umar b. al-Khattâb ketika memindahkan mesjid Kufah dari tempat yang lama ke tempat yang baru. Demikian pula, terhadap Masjid Nabawî, 'Umar dan Uthmân pernah memperbaiki dan memperluasnya di atas tanah yang bukan bekas bangunan masjid semula.

\section{Boleh Mengangkat Beberapa Orang Khalifah di Dunia Islam}

Di antara fleksibilitas fikih Ibn Taymiyyah dalam bidang mu'amalah adalah ijtihadnya yang membolehkan dunia Islam memiliki dua orang atau lebih kepala negara dengan beberapa negara. Menurutnya, umat Islam tidak diharuskan hanya mempunyai satu negara dengan seorang kepala negara. ${ }^{47}$

Sama dengan pendapat umumnya umat Islam, Ibn Taymiyyah berpendirian bahwa urusan memimpin orang banyak, termasuk pemimpin negara dan kepala pemerintahan, merupakan salah satu kewajiban terpenting lainnya yang diperintahkan agama. Allah, kata Ibn Taymiyyah, mewajibkan umat Islam untuk menegakkan amar makruf nahi munkar. Tugas menyuruh manusia untuk berbuat baik dan mencegah mereka dari perbuatan mungkar, tidak akan sempurna dan terlaksana tanpa ada kekuasaan dan pemerintahan. ${ }^{48}$

Inti doktrin pilitik Ibn Taymiyyah adalah terwujudnya syariat Islam secara benar dan baik, sedangkan negara hanya merupakan alat untk menegakkan syariat. Maka, mudah dimengerti jika ia memberi kemungkinan bagi adanya pluralisme negara dan pemerintahan dalam dunia Islam seperti yang dikenal sekarang.

Itulah beberapa contoh ijtihad Ibn Taymiyyah, yang tampak berbeda dengan kebanyakan fuqahâ'. Masih terdapat ijtihad Ibn Taymiyyah yang menyalahi pendapat jumhur seperti di antaranya: 1) Orang yang jika ingin shalat Jum'at, boleh bertayammum meskipun ada air; 2) Orang yang dianjurkan memperbanyak amalanamalan sunnah agar dosanya dihapuskan sebagaimana orang yang melakukan haji dengan cara qirân dan ifrâd; 4) Tidak ada ketentuan batas minimal dan maksimal masa haid wanita; 5) Masa iddah wanita yang tertalak-khulû' cukup hanya sekali haid; 6) Suami yang bersumpah hendak menalak istrinya dan kemudian ternyata tidak menalaknya, talaknya tidak dianggap jatuh, namun ia (suami) wajib membayar kaffârah yamîn (sumpah). ${ }^{49}$

47 Ibn Taymiyyah, Minhaj al-Sunnah al-Nabawiyyah fî Naqd Kalâm al-Shî̀ah wa alQadariyyah, Jilid 2, (Beirut: Dâr al-Kutub al-'Ilmiyyah, t.th.), hal. 223.

48 Ibn Taymiyyah, al-Siyâsah al-Shar'iyyah fî Islâh al-Râ'î wa al-Ra'iyyah, (Beirut: Dâr al-Âfâq al-Jadîdah, 1983), hal. 138.

49 Lihat Musa, Ibn Taymiyyah, hal. 235-236; Abu Zahrah, Ibn Taymiyyah, hal. 406-421. 


\section{G. Penutup}

Berdasarkan uraian di atas, dapat ditarik kesimpulan sebagai berikut:

1. Pada dasarnya, Ibn Taymiyyah adalah seorang pemikir empiris, menurutnya, segenap pengetahuan ihwal dunia eksternal dihasilkan dari hasil observasi atas hal-hal partikular. Dalam pemikiran keagamaan Alquran dan Sunnah menjadi dasar utama. Ayat-ayat Alquran harus dipahami secara benar sesuai apa yang tertulis dalam kitab dan tidak boleh ditakwilkan.

2. Ibn Taymiyyah adalah seorang mujtahid, yang disebut sebagai "mujtahid mutlak" atau "mujtahid mandiri”, dalam pengertian, tidak terikat dengan mazhab tertentu, termasuk di dalamnya mazhab H?anbalî.

3. Ibn Taymiyyah bebas menerima atau menolak pendapat mujtahid lain dari lingkungan mazhab manapun.

4. Meskipun pada mulanya Ibn Taymiyyah adalah seorang mengikut Hanbaliyah, namun terdapat beberapa perbedaan dalam hal-hal tertentu antara Ibn Taymiyyah dengan Ibn Hanbal, baik dari segi sumber hukum yang diperpegangi, maupun metode dan hasil ijtihad antara keduanya, dan juga perbedaan dengan mujtahid dan mazhab lainnya.

\section{DAFTAR PUSTAKA}

Arkoun, Muhammad, al-Islâm: al-Akhlâq wa al-Siyâsah, Terj. Hashim Saleh, Beirut: Markaz al-Inmâ’ al-Qawmî, 1990

'Asqalânî, Ibn Hajar, Bulughul Maram, Terj. Ahmad b. Sa'ad b. Nabhan, Surabaya: tp., tth.

al-Baytar, Muhammad Bahjah, Hayât Shaykh al-Islâm Ibn Taymiyyah, Beirut: alMaktabah al-Islâmiyyah, t.th.

Dewan Redaksi, Ensiklopedi Islam. Jilid 2, Cet. ke-3, Jakarta: Ichtiar Baru Van Hoeve, 1994

al-Ghanî, Ahmad b Muhammad b 'Abd, al-Musawwadah fî Usûl al-Fiqh, Mesir: Matba'ah al-Madanî, t.th

Hâfiz, 'Abd al-Salâm Hâshim, al-Imâm Ibn Taymiyyah, Mesir: Mustafâ al-Bâb alHalabî, 1969

al-Hasan, Alâ' al-1̂in Abû, al-Akhbâr al-Ilmiyyah min al-Ikhtiyârât al-Fiqhiyyah min Fatâwâ Shaykh al-Islâm Ibn Taymiyyah, Beirut: Dâr al-Fikr, t.th. 
Heer, Nicholas, "Ibn Taymiyah’s Empiricism” dalam Farhad Kazemi dan R.D. McChesney, A Way Prepared, New York: New York University Press, 1988, h. $109-115$

Ibn Taymiyyah, Ahmad Ibn dan Ibn al-Qayyim al-Jawziyyah, Majmû' Fatâwâ Ibn Taymiyyah, Juz 33, t.tp.: Dâr 'Âlam al-Kutub, t.th. , al-Qiyâs fî al-Shar' al-Islâmî, Beirut: Dâr al-Âfâq al-Jadîdah, 1982. , al-Siyâsah al-Shar'iyyah fî Islâh al-Rầî wa al-Ra'iyyah, Beirut: Dâr al-Âfâq alJadîdah, 1983

, Iqtidâ’ al-Sirât al-Mustaqîm Mukhâlafah Ah?zâb al-Tahîm, Beirut: Dâr alFikr, t.th.

, Minhaj al-Sunnah al-Nabawiyyah fî Naqd Kalâm al-Shî̉ah wa al-Qadariyyah, Jilid 2, Beirut: Dâr al-Kutub al-'Ilmiyyah, t.th.

, Rasâ'il wa Masâil Ibn Taymiyyah, t.tp.: Dâr al-Nasyr, t. th.

al-Jawziyah, Ibn Qayyim, I’lâm al-Muwaqi'în 'an Rabb al-'Âlamîn, Jilid 2, Beirut: Dâr al-Jalîl, t.th.

al-Jaza'irî, 'Abd al-Rahmân, Kitâb al-Fiqh 'alâ al-Madhâhib al-Arba’ah, Jilid 1, Beirut: Dâr al-Fikr, tt

Kathîr, Muh?ammad b. Ismâ’îl Ibn, al-Bidâyah wa al-Nihâyah, Jilid 9, Beirut: Dâr al-Fikr, t.th.

Laoust, Henri, “Ibn Taymiyyah” dalam Encyclopædia Britannica online: http:// www.britannica.com/EBchecked/topic/280847/Ibn-Taymiyyah (Diakses 18 Agustus 2010)

Madjid, Nurcholis (ed), Khazanah Intelektual Islam. Cet. ke-3, Jakarta: Bulan Bintang, 1984

, “Ibn Taymiyyah on Kalam and Falsafah”, Disertasi, University of Chicago, Ilhonis, 1984

Mughniyyah, Muhammad Jawâd, al-Ahwâl al-Shakhsiyyah 'alâ al-Madhâhib alKhamsah, Beirut: Dâr al-'Ilm li al-Malayîn, 1964

Mûsâ, Muhammad Yûsuf, Ibn Taymiyyah. Mesir: Maktabah al-Misr, tth

"Polemik Sosiologi Pembaruan Pemikiran Islam Nurcholish Madjid”, dalam Jurnal Ulumul Qur'an, Vol. 4, No. 1, 1993 
Rushd, Muhammad b. Ahmad Ibn, Bidâyat al-Mujtahid wa Nihâyat al-Muqtas?id, Jilid 1, Mesir: Mustafâ al-Bâbi al-Halabî, 1960

Sâlihb. 'Abd al-Azîz 'Alî Mansûr, Usûl al-Fiqh wa Ibn Taymiyyah. Jilid 2, t.p., t.t., t.th

Suryadi AR., Didi, “Ibn Taymiyyah: Telisik Metodologi dalam Pemikiran” dalam http://saungtinta.multiply.com/journal/item/17/IBNU_ TAIMIYAH_ Telisik_Metodologi_dalam_Pemikiran (diakses 26 Agustus 2010)

Zahrah, Muhammad Abû, Ibn Taymiyyah: Hayâtuhu wa 'Asruhu Arâ'uhu wa Fiqhuhu, Mesir: Mustafâ al-Babi al-Halabî, 1969

al-Zayn, Muhammad Husnî, Mantiq Ibn Taymiyyah wa Manhajuhu al-Fikrî, Beirut: al-Maktabah al-Islâmiyyah, 1979

al-Zuhayli, Wahbah, al-Fiqh al-Islâmiy wa Adillatuh, Juz II, Cet. II; Damasqus: Dar al-Fikr, 1985 
